\title{
Deducing the Crystal Structure of MERS-CoV Helicase
}

\section{Sheng Cui and Wei Hao}

\begin{abstract}
RNA virus encodes a helicase essential for viral RNA transcription and replication when the genome size is larger than $7 \mathrm{~kb}$. Coronavirus $(\mathrm{CoV})$ has an exceptionally large RNA genome $(\sim 30 \mathrm{~kb})$ and it encodes an essential replicase, the nonstructural protein 13 (nspl3), a member of superfamily 1 helicases. Nspl3 is among the evolutionary most conserved proteins not only in CoVs but also in nidovirales. Thus, it is considered as an important drug target. However, the high-resolution structure of CoV nspl3 remained unavailable even until more than a decade after the outbreak of the severe acute respiratory syndrome coronavirus (SARS-CoV) in 2003, which hindered the structure-based drug design. This is in part due to the intrinsic flexibility of nspl3. Here, we describe protocols of deducing the crystal structure of Middle East respiratory syndrome coronavirus (MERS-CoV) helicase in detail, which include protein expression, purification, crystallization, enzymatic characterization, and structure determination. With these methods, catalytically active recombinant MERS-CoV nspl3 protein can be prepared and crystallized and the crystal structure can be solved.
\end{abstract}

Key words Coronavirus, Helicase, nsp13, Crystallization, Structure determination

\section{Introduction}

Coronavirus $(\mathrm{CoV})$ remains a public health concern 16 years after the outbreak of the severe acute respiratory syndrome coronavirus (SARS-CoV) in 2003 [1]. The Middle East respiratory syndrome coronavirus (MERS-CoV) emerged in 2012, reemerged in 2015, and is still circulating in the Middle East region, which reminds the international community that the threat of CoVs persists $[2,3]$. However, neither vaccine nor drugs against CoVs are currently available. Outbreaks of CoVs initiated extensive structural investigation on $\mathrm{CoV}$ encoded proteins thereafter, which not only shed light on the life cycle of CoVs but also laid foundation for the structure-based drug design (SBDD). CoV contains a positive single-stranded RNA genome of $\sim 30 \mathrm{~kb}$, one of the largest among +RNA viruses [4, 5]. To maintain the unusually large RNA genome, CoV encodes two replicase polyproteins ppla and pplab, which are broken down into 16 nonstructural proteins 
(nsps) via proteinase cleavage $[6,7]$. The nsps are then recruited to cytoplasm membranes, on which they form the membraneassociated replication-transcription complex (RTC). An RNAdependent RNA polymerase nspl2 and a helicase nspl3 are the central components of RTC $[8,9]$. However, while high-resolution structures of most $\mathrm{CoV}$ encoded proteins had been determined soon after SARS-CoV outbreak, the first CoV nspl3 structure, MERS-CoV nspl3, was only solved recently [10]. Nspl3 belongs to helicase superfamily 1 and shares conserved features with the eukaryotic Upfl helicase $[11,12]$. Nspl3 is a multi-domain protein comprising of an $\mathrm{N}$-terminal Cys/His rich domain ( $\mathrm{CH}$ domain) and a C-terminal SF1 helicase core [10]. Nspl3 exhibits multiple enzymatic activities, including hydrolysis of NTPs and dNTPs, unwinding of DNA and RNA duplexes with $5^{\prime}-3^{\prime}$ directionality and the RNA $5^{\prime}$-triphosphatase activity $[13,14]$. To investigate the structure of CoV nspl3, we overexpressed the full-length MERS-CoV nspl3 (1-598aa) in insect cells and purified. The activity of the recombinant MERS-CoV nspl3 was verified by ATPase and helicase assays. Crystallization of MERS-CoV nspl3 was achieved by adding a synthetic single-stranded 15 poly dT DNA with $5^{\prime}$-triphosphate (ppp-15 T) to the protein, which restrains the intrinsic flexibility of nspl3. Benefiting from the presence of an $\mathrm{N}$-terminal zinc-binding domain with three zinc atoms, multi-wavelength anomalous diffraction (MAD) data at the zinc absorption edge was collected, which allowed the determination of the crystal structure of MERS-CoV nspl3 [10].

\section{Materials}

\subsection{Gene Cloning}

Prepare all solutions using ultrapure water (prepared by purifying deionized water, to attain a sensitivity of $18 \mathrm{M} \Omega-\mathrm{cm}$ at $25^{\circ} \mathrm{C}$ ) and analytical grade reagents. Prepare and store all reagents at room temperature (unless indicated otherwise). Diligently follow all waste disposal regulations when disposing waste materials. We do not add sodium azide to reagents.

1. Full-length MERS-CoV(GenBank accession: YP_009047202) nspl3 gene cDNA (GenScript).

2. The forward primer (gaaattggatccgctgtcggttcatgc) and the reverse primer (gaaattctcgagtcactggagcttgtaatt) of full-length nspl3. Primers stocks are either supplied or diluted by molecular biology grade water to $100 \mu \mathrm{M}$ and stored at $-20{ }^{\circ} \mathrm{C}$.

3 . The pFastbac- 1 baculovirus transfer vector is modified; $6 \times$ Histidine-SUMO tag with a $\mathrm{C}$ terminal PreScission protease (PPase) site coding sequence in the $\mathrm{N}$ terminal of open reading frame [15]. 
4. Chemically competent bacterial cells of E. coli BL21 and E. coli $\mathrm{DH} 10 \mathrm{Bac}$ are prepared in-house as described.

5. High-fidelity PCR master mix with HF buffer $(2 \times$ fusion $)$.

6. Endonuclease $B a m \mathrm{HI}$ and $X h o \mathrm{I}$ (fast digest).

7. $50 \times$ TAE buffer $(1 \mathrm{~L}): 242 \mathrm{~g}$ Tris base, $57.1 \mathrm{~mL}$ glacial acetic acid and $100 \mathrm{~mL}$ of $0.5 \mathrm{M}$ EDTA, $\mathrm{pH} 8.0, \mathrm{pH}$ adjusted to 8.5. Filtered through a $0.2 \mu \mathrm{m}$ membrane filter and used as a $1 \times$ solution.

8. Rapid DNA ligation kit (Promega).

9. LB medium: 5 g yeast extract, $10 \mathrm{~g}$ tryptone, and $10 \mathrm{~g} \mathrm{NaCl}$ are dissolved in $800 \mathrm{~mL}$ water. Volume is adjusted to $1000 \mathrm{~mL}$ and autoclaved on the same day.

10. LB-agar: 5 g yeast extract, $10 \mathrm{~g}$ tryptone, $10 \mathrm{~g} \mathrm{NaCl}$, and $15 \mathrm{~g}$ agar are dissolved in $800 \mathrm{~mL}$ water. Volume is adjusted to $1000 \mathrm{~mL}$ and autoclaved on the same day.

11. $1000 \times$ Antibiotic stocks: Ampicillin $(100 \mathrm{mg} / \mathrm{mL})$; Kanamycin $(50 \mathrm{mg} / \mathrm{mL})$; Tetracycline $(10 \mathrm{mg} / \mathrm{mL}$ in ethanol); Gentamycin $(7 \mathrm{mg} / \mathrm{mL})$, stored at $-20{ }^{\circ} \mathrm{C}$. All stocks prepared in water are filtered through a $0.22 \mu \mathrm{m}$ syringe filter.

\subsection{Bac-to-Bac}

Baculovirus

Expression

\subsection{Test Expression}

\subsection{Large-Scale Expression and Purification}

1. Blue-gal ( $100 \mathrm{mg} / \mathrm{mL}$ in DMSO $)$;PTG $(40 \mathrm{mg} / \mathrm{mL})$ stored at $-20{ }^{\circ} \mathrm{C}$. All stocks prepared in water are filtered through a 0.22 and $0.45 \mu \mathrm{m}$ syringe filter.

2. Bacmid transfection reagent.

3. Bacmid extract kit (plasmid mini kit (100)) (Qiagen).

4. Insect cell: Sf21 and High-5 (Invitrogen).

5. Insect cell media: Sf900II medium and High express five (Invitrogen); SIM HF (Sino Biological Inc).

6. $75 \mathrm{~cm}^{2}$ flasks.

1. Lysis and wash buffer (I): $25 \mathrm{mM}$ Tris-HCl, $\mathrm{pH} 7.5,150 \mathrm{mM}$ $\mathrm{NaCl}, 20 \mathrm{mM}$ imidazole.

2. Elution buffer: $25 \mathrm{mM}$ Tris- $\mathrm{HCl}, \mathrm{pH} 7.5,150 \mathrm{mM} \mathrm{NaCl}$, $250 \mathrm{mM}$ imidazole.

3. Ni-IDA Metal Chelate Resin (Qiagen).

1. Lysis and wash buffer(II): $25 \mathrm{mM}$ Tris- $\mathrm{HCl}, \mathrm{pH} 7.5,1.5 \mathrm{M}$ $\mathrm{NaCl}, 20 \mathrm{mM}$ imidazole.

2. PreScission protease (PPase) was prepared in-house.

3. Econo-Columns.

4. Amicon Ultra protein concentrators (Millipore). 


\subsection{ATPase Assay}

\subsection{Helicase Assay}

\subsection{Crystallization}

2.8 Structure Determination
5. Size Exclusion Chromatography (SEC) buffer: $10 \mathrm{mM}$ HEPES, pH 7.0, $100 \mathrm{mM} \mathrm{NaCl}$. Filtered through a $0.2 \mu \mathrm{m}$ membrane filter and stored at $4{ }^{\circ} \mathrm{C}$.

6. Size-exclusion chromatography (Superdex-200) (GE healthcare).

1. $\left[\gamma^{-32} \mathrm{P}\right] \mathrm{ATP}$.

2. ATP is dissolved by water to $1 \mathrm{mM}$.

3. $5 \times$ ATPase reaction buffer: $20 \mathrm{mM} \mathrm{MgCl}_{2}, 500 \mathrm{mM}$ Tris$\mathrm{HCl}, \mathrm{pH}$ 8.0.

4. The thin-layer chromatography cellulose (TLC) plates.

5. ATPase reaction quenching buffer: 0.5 M EDTA.

6. TCL plates running buffer: $0.8 \mathrm{M}$ acetic acid and $0.8 \mathrm{M} \mathrm{LiCl}$.

7. Typhoon Trio Variable Mode Imager.

1. ATP, GTP, CTP, and TTP.

2. Trap RNA (5'-CGAAGCUGCUAACAUCAG- $\left.3^{\prime}\right)$, top strand RNA (5'-UUUUUUUUUUCUGAUGUUAGCAGCUUC G- $\left.3^{\prime}\right)$, and bottom stand RNA with a $5^{\prime}$-HEX tag $\left(5^{\prime}\right.$-HEX-C GAAGCUGCUAACAUCAG- $3^{\prime}$ ).

3. The partial duplex RNA substrate with $5^{\prime}$ overhang is prepared by mixing the top strand RNA and the $5^{\prime}$-HEX tagged bottom strand.

4. $10 \times$ Helicase reaction buffer: $500 \mathrm{mM}$ Hepes, $\mathrm{pH} 7.5,50 \mathrm{mM}$ $\mathrm{MgCl}_{2}, 20 \mathrm{mM}$ DTT, and $0.1 \% \mathrm{BSA}$.

5. $5 \times$ loading buffer: $100 \mathrm{mM}$ Tris- $\mathrm{HCl}, \mathrm{pH} 7.5,50 \%$ glycerol, and $1 \%$ SDS.

6. $10 \times$ TBE buffer:108 g Tris, $7.44 \mathrm{~g} \mathrm{Na}_{2}$ EDTA. $2 \mathrm{H}_{2} \mathrm{O}, 55 \mathrm{~g}$ boric acid, dissolved by water and adjusted the volume to $1 \mathrm{~L}$.

7. $6 \%$ native PAGE gel: $1 \mathrm{~mL} 10 \times$ TBE, $5.2 \mathrm{~mL} 30 \%$ polyacrylamide, $0.39 \mathrm{~mL}$ glycerol $(50 \%), 13.25 \mathrm{~mL} \mathrm{H}_{2} \mathrm{O}, 0.15 \mathrm{~mL}$ ammonium persulfate (10\%), and $0.01 \mathrm{~mL}$ TEMED.

1. Crystallization screen kits (Hampton and Qiagen).

2. 5'-triphosphate DNA (ppp-15T) are synthesized and purified according to previously published procedures $[16,17]$.

3. 24-Well vapor diffusion crystallization plates.

4. Crystallization conditions screen kits are supplied by Hampton research.

The software that are used in structure determination include XDS, Coot, SHARP/autoSHARP, PHENIX, and Pymol. 
3 Methods

All procedures should be carried out at room temperature unless otherwise specified.

\subsection{Transfer Plasmid Construction and Transposition in E. coli DH10 Bac}

1. Amplify MERS-nspl3 full-length by PCR method with BamHI and XhoI restriction sites at $5^{\prime}$ and $3^{\prime}$ termini, respectively.

2. The amplified MERS-nspl3 gene should be digested by $\mathrm{BamHI} / \mathrm{XhoI}$ at $37^{\circ} \mathrm{C}$ for $1 \mathrm{~h}$. The pFast-bac- $6 \times$ HistidineSUMO plasmid should also be digested by BamHI/XhoI at the same time.

3. Digested nspl3 DNA should be ligated with pFast-bac$6 \times$ Histidine-SUMO vector using the rapid DNA ligation kit. The ligation system: $100 \mathrm{ng}$ DNA, $35 \mathrm{ng}$ vector, $10 \times$ reaction buffer and T4 ligase, mixed and incubated at room temperate for $2 \mathrm{~h}$.

4. Add $10 \mu \mathrm{L}$ mixture of ligation product to $100 \mu \mathrm{L}$ E. coli BL2 1 competent cells in a $1.5 \mathrm{~mL}$ Eppendorf tube and incubate on ice for $30 \mathrm{~min}$. Heat shock the cells for $90 \mathrm{~s}$ in a $42{ }^{\circ} \mathrm{C}$ water bath and return briefly to ice. After $2 \mathrm{~min}$, add $300 \mu \mathrm{L} \mathrm{LB}$ medium and incubate in a shaker at $37^{\circ} \mathrm{C}$ and shake at $200 \mathrm{rpm}$ for $1 \mathrm{~h}$.

5. Spread the culture onto the LB plate containing Ampicillin $(100 \mu \mathrm{g} / \mathrm{mL})$, and incubate at $37^{\circ} \mathrm{C}$ for $14-16 \mathrm{~h}$.

6. Pick single colonies and inoculate to $500 \mu \mathrm{L} \mathrm{LB}$ medium. Incubate cultures at $37{ }^{\circ} \mathrm{C}$ and shake at $200 \mathrm{rpm}$ for $4 \mathrm{~h}$. Send the cultures for sequencing.

7. Collect the positive colonies and extract the recombinant plasmids according to the sequencing result.

8. Add 20 ng recombinant plasmid to $50 \mu \mathrm{L}$ E. coli DHl0 Bac competent cells in a $1.5 \mathrm{~mL}$ Eppendorf tube and incubate on ice for $30 \mathrm{~min}$. Heat shock the cells for $90 \mathrm{~s}$ in a $42{ }^{\circ} \mathrm{C}$ water bath and return briefly to ice. 2 min later, add $500 \mu \mathrm{L} \mathrm{LB}$ medium and incubate in a shaker at $37{ }^{\circ} \mathrm{C}$ and shake at $200 \mathrm{rpm}$ for $5 \mathrm{~h}$.

9. Prepare bacmid selection plates containing approximately $10 \mathrm{~mL}$ of LB-agar, supplemented with $50 \mu \mathrm{g} / \mathrm{mL}$ kanamycin, $7 \mu \mathrm{g} / \mathrm{mL}$ gentamycin, $10 \mu \mathrm{g} / \mathrm{mL}$ tetracycline, $40 \mu \mathrm{g} / \mathrm{mL}$ IPTG, and $100 \mu \mathrm{g} / \mathrm{mL}$ Blue-gal, and once set allow to dry, inverted at room temperature.

10. Spread $50 \mu \mathrm{L}$ culture onto the bacmid selection plate and incubate at $37^{\circ} \mathrm{C}$ for up to $60 \mathrm{~h}$. 


\subsection{Production of MERS-CoV nsp13 bacmid}

\subsection{Production of MERS-CoV nsp13 Recombinant Virus}

1. Pick single white colony from the bacmid selection plate (white colonies contain the recombinant bacmid DNA and the blue ones do not). Inoculate it to $15 \mathrm{~mL} \mathrm{LB}$ (containing $50 \mu \mathrm{g} / \mathrm{mL}$ kanamycin, $7 \mu \mathrm{g} / \mathrm{mL}$ gentamycin, $10 \mu \mathrm{g} / \mathrm{mL}$ tetracycline) and incubate at $37^{\circ} \mathrm{C}$ with shaking at $220 \mathrm{rpm}$ for up to $5 \mathrm{~h}$.

2. Centrifuge the culture at $3000 \times g$ for $20 \mathrm{~min}$. Remove the supernatant carefully. Add $1.2 \mathrm{~mL}$ solution $\mathrm{Pl}$ from the bacmid extract kit (plasmid mini kit (100) from Qiagen) and resuspend the precipitate.

3. Add $1.2 \mathrm{~mL}$ solution $\mathrm{P} 2$, mix thoroughly by softly inverting 6-8 times, and incubate at room temperature (about $25^{\circ} \mathrm{C}$ ) for $5 \mathrm{~min}$.

4. Add $1.2 \mathrm{~mL}$ solution $\mathrm{P} 3$, mix thoroughly by softly inverting 6-8 times. Incubate it on ice for $5 \mathrm{~min}$.

5. Centrifuge at $15,000 \times g$ for $10 \mathrm{~min}$ at $4{ }^{\circ} \mathrm{C}$. Apply the supernatant to the QIAGEN-tip and allow it to enter the resin by gravity flow.

6. Wash the QIAGEN-tip with $2 \times 2 \mathrm{~mL}$ Buffer QC. Elute DNA with $0.8 \mathrm{~mL}$ Buffer QF into a clean $1.5 \mathrm{~mL}$ Eppendorf tube.

7. Precipitate DNA with $0.56 \mathrm{~mL}$ isopropanol and wash the pellet with $1 \mathrm{~mL} 70 \%$ ethanol. Dry the pellet and resuspend in $20 \mu \mathrm{L}$ sterilized $\mathrm{ddH}_{2} \mathrm{O}$.

1. Seed $0.8 \times 10^{6} \mathrm{Sf} 21$ cells in duplicates in 6-well plates and incubate for $15-30 \mathrm{~min}$ at $28{ }^{\circ} \mathrm{C}$ ( see Notes 1 and 2$)$.

2. Prepare transfection reagent solution of $100 \mu \mathrm{L}$ SF $900 \mathrm{II}$ media (nonantibiotic) with $6 \mu \mathrm{L}$ transfection reagents. Prepare bacmid solution of $100 \mu \mathrm{L}$ SF 900 II media (nonantibiotic) with $4 \mu \mathrm{L}$ dissolved bacmid. Mix the two solutions and rest at $28{ }^{\circ} \mathrm{C}$ for $30 \mathrm{~min}$.

3. Add $800 \mu \mathrm{L}$ SF 900 II media (nonantibiotic) to the mixture, and transfer them to the 6-well plates in stepl (after removing supernatant and washed by nonantibiotic media twice). Prior to addition of SF90II media to the 6-well plates make sure to remove the supernatant and wash twice with nonantibiotic media. Incubate the 6 -well plate at $28{ }^{\circ} \mathrm{C}$ for $5 \mathrm{~h}$.

4. Remove the supernatant of the plates and add $2.5 \mathrm{~mL}$ fresh media with $10 \mu \mathrm{g} / \mathrm{mL}$ gentamycin. Incubate at $28^{\circ} \mathrm{C}$ for $72 \mathrm{~h}$. Observe the cells under the microscope. Collect the supernatant if the cells present noticeable infected symptoms (swelling, splitting, and stop growing), and centrifuge at $453 \times g$ for 5 min. Collect the supernatant. This will be Pl virus.

5. Prepare $75 \mathrm{~cm}^{2}$ flasks containing $15 \mathrm{~mL} \mathrm{Sf} 21$ cell suspension at a density of $0.4-0.6 \times 10^{6}$ cells $/ \mathrm{mL}$. Make sure the cells are distributed evenly in the flasks, incubate at $28{ }^{\circ} \mathrm{C}$ for $20 \mathrm{~min}$. 
6. Add $0.4 \mathrm{~mL} \mathrm{Pl}$ virus to the $15 \mathrm{~mL} \mathrm{Sf} 21$ cells culture in $75 \mathrm{~cm}^{2}$ flask. Incubate at $28{ }^{\circ} \mathrm{C}$ for $48-60 \mathrm{~h}$. Observe the cells under the microscope and collect the supernatant from the flasks, centrifuge at $453 \times g$ for $5 \mathrm{~min}$. Collect the supernatant. This will be $\mathrm{P} 2$ virus.

7. Prepare $75 \mathrm{~cm}^{2}$ flasks containing $15 \mathrm{~mL} \mathrm{Sf} 21$ cells suspension at a density of $0.6-1.0 \times 10^{6}$ cells $/ \mathrm{mL}$. Make sure the cells are distributed evenly in the flask, incubate at $28{ }^{\circ} \mathrm{C}$ for $20 \mathrm{~min}$.

8. Infect the $15 \mathrm{~mL} \mathrm{Sf} 21$ cell culture in $75 \mathrm{~cm}^{2}$ flask with $0.4 \mathrm{~mL}$ $\mathrm{Pl}$ virus. Incubate at $28{ }^{\circ} \mathrm{C}$ for $48-60 \mathrm{~h}$. Observe the cells under the microscope and collect the supernatant from the flasks, centrifuge at $453 \times g$ for $5 \mathrm{~min}$. Collect the supernatant (P3 virus).

\subsection{Test Expression of MERS-CoV nsp13}

3.5 Large-Scale Expression and Purification of MERSCoV nsp13
1. Prepare $50 \mathrm{~mL}$ high -5 cells in express -5 medium at a density of $0.38 \times 10^{6}$ cells $/ \mathrm{mL}$, and culture in a $300 \mathrm{~mL}$ cell conical flask. Incubate the culture at $28{ }^{\circ} \mathrm{C}$ with shaking at $120 \mathrm{rpm}$ for $48 \mathrm{~h}$, the density of cells will grow to $1.5-2.5 \times 10^{6}$ cells $/ \mathrm{mL}$ (see Note 2).

2. Add $1.5 \mathrm{~mL}$ MERS-CoV nspl3 P2 or P3 virus into the culture, and incubate at $22{ }^{\circ} \mathrm{C}$ with shaking at $120 \mathrm{rpm}$ for $44-60 \mathrm{~h}$.

3 . Centrifuge the culture at $3000 \times g$ for $30 \mathrm{~min}$. Collect the cells pellet.

4. Quickly freeze the cells pellet by liquid nitrogen. Resuspend the pellet by $5 \mathrm{~mL}$ lysis and wash buffer (I) and incubate on ice for up to $10 \mathrm{~min}$.

5. Centrifuge at $15000 \times g$ for $20 \mathrm{~min}$ at $4{ }^{\circ} \mathrm{C}$. Apply the supernatant to the mini-affinity column with $300 \mu \mathrm{L}$ Ni-IDA Metal Chelate Resin and allow it to enter the resin by gravity flow at $4{ }^{\circ} \mathrm{C}$.

6. Wash the resin with $1 \mathrm{~mL}$ lysis and wash buffer (I) three times.

7. Load $600 \mu \mathrm{L}$ elution buffer to the resin and allow it to enter the resin by gravity flow. Collect the eluted sample into a $1.5 \mathrm{~mL}$ Eppendorf tube.

8. Pick $8 \mu \mathrm{L}$ eluted sample and mix with $2 \times$ loading buffer.

9. Load SDS-PAGE gel and run at $200 \mathrm{~V}$ for $60 \mathrm{~min}$. The result of expression is visualized by Coomassie brilliant blue stain (Fig. 1).

1. Prepare 1 to $1.5 \mathrm{~L}$ high- 5 cells in HF medium at a density of $0.38 \times 10^{6}$ cells $/ \mathrm{mL}$, and culture in $3 \mathrm{~L}$ cell conical flask (keep the volume of culture to $500-750 \mathrm{~mL}$ in a $3 \mathrm{~L}$ flask). Incubate the culture at $28{ }^{\circ} \mathrm{C}$ with shaking at $120 \mathrm{rpm}$ for $40-48 \mathrm{~h}$, then to the density of cells will grow to $1.5-2.5 \times 10^{6}$ cells $/ \mathrm{mL}$ (see Note 3). 


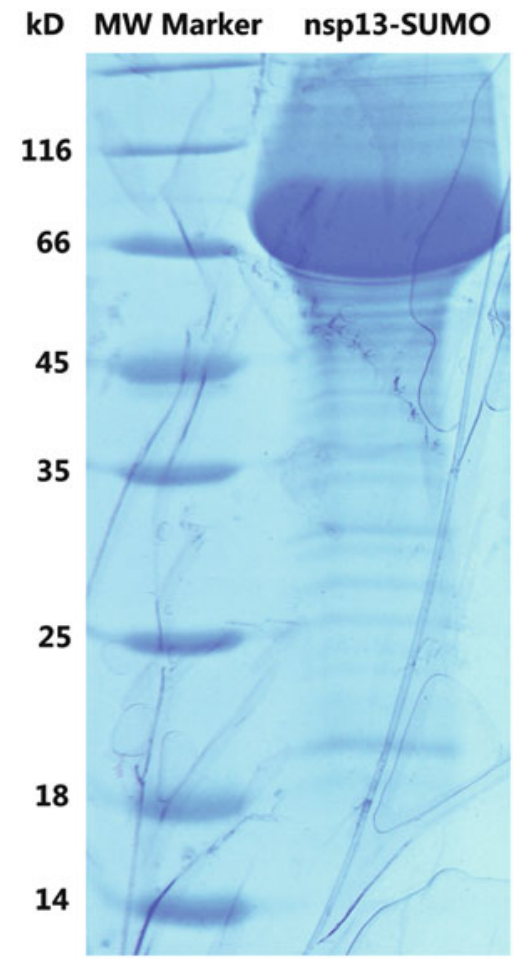

Fig. 1 Test expression of MERS-CoV nsp13. The eluted MERS-CoV nsp13 protein possesses an 6-Histidine and SUMO tag. $8 \mu \mathrm{L}$ sample was loaded on the SDS-PAGE gel and the result was visualized by Coomassie brilliant blue stain

2. Add 30-45 mL MERS-CoV nspl3 P3 virus to the culture $(30 \mathrm{~mL}$ virus $/ \mathrm{L}$ culture $)$. Incubate the culture at $22{ }^{\circ} \mathrm{C}$ with shaking at $120 \mathrm{rpm}$ for $40-48 \mathrm{~h}$.

3. Centrifuge the culture at $3000 \times g$ for $30 \mathrm{~min}$. Collect the cell pellet.

4. Resuspend the pellet by 100-150 mL lysis and wash buffer (II) $(100 \mathrm{~mL}$ buffer $/ 1$ L culture's pellet). Add $600-900 \mu \mathrm{L}$ $0.1 \mathrm{M}$ PMSF to the cell suspension $(600 \mu \mathrm{L}$ PMSF $/ 100 \mathrm{~mL}$ cell suspension).

5. Place the cell suspension on ice-water mixture. Set the amplitude to $30 \%$ on a $750 \mathrm{~W}$ cell sonicator and sonicate with bursts of $3 \mathrm{~s}$ on, $5 \mathrm{~s}$ off.

6. Transfer the lysates to centrifuge tubes, balance the tubes pairwise and centrifuge at $15000 \times g$ for $1 \mathrm{~h}$ at $4{ }^{\circ} \mathrm{C}$.

7. Transfer the supernatant to new centrifuge tubes and re-centrifuge at $15,000 \times g$ for $1 \mathrm{~h}$ at $4{ }^{\circ} \mathrm{C}$.

8. Transfer the clear supernatant into clean tubes taking care to avoid transferring any pelleted material.

9. Filter the supernatant by $0.45 \mu \mathrm{m}$ syringe filter. This clarified supernatant represents the soluble fraction. 
10. Prepare the Ni-NTA resin, and add the resin into 2-3 empty Econo-Columns (5 mL 50\% resin per column), wash and balance the resin with $10 \mathrm{~mL}$ lysis and wash buffer(II) twice.

11. Place the columns at $4^{\circ} \mathrm{C}$. Apply the clarified cell lysates supernatant to the balanced Ni-NTA resin, and flow through the column by gravity.

12. Wash the resin in the column with $10 \mathrm{~mL}$ lysis and wash buffer (II) 3 times.

13. Resuspend the resin by $3.5 \mathrm{~mL}$ L lysis and wash buffer(II), and add $100 \mu \mathrm{L}$ PPase. Incubate the resin at $4{ }^{\circ} \mathrm{C}$ for $10-12 \mathrm{~h}$.

14. Apply the buffer to the column and let it flow under gravity. Collect the flow through in a $50 \mathrm{~mL}$ tube.

15. Add another $25 \mathrm{~mL}$ lysis and wash buffer(II) to the resin and flow through the column. Also collect the flow through in the previous $50 \mathrm{~mL}$ tube.

16. To remove the PPase, add the flow through to another column which contains the NS4B resin. Collect the flow through from the NS4B resin column.

17. Apply the flow through to an Amicon Ultra protein concentrator $(30 \mathrm{kDa}$ filter, $50 \mathrm{~mL})$, centrifuge at $2465 \times g$ at $4{ }^{\circ} \mathrm{C}$ until the sample volume is concentrated to $1 \mathrm{~mL}$.

18. Transfer the concentrated sample to a $1.5 \mathrm{~mL}$ tube and centrifuge at $17,949 \times g$ for $3 \mathrm{~min}$ to remove the aggregates and particulates.

19. Load the sample onto the superdex 200 column in the size exclude chromatography (SEC) buffer using an ÄKTA-purify chromatography at $4{ }^{\circ} \mathrm{C}$.

20. Analyze $8 \mu \mathrm{L}$ of each peak fractions by SDS-PAGE (Fig. 2).

21. Collect the fractions that contain the single band of MERS$\mathrm{CoV}$ nspl3, mix the fractions, and concentrate the mixture to a final density of $6-8 \mathrm{mg} / \mathrm{mL}$.

22. $50 \mu \mathrm{L}$ packaged the protein sample, quickly freeze them by liquid nitrogen and store them at $-80{ }^{\circ} \mathrm{C}$.

3.6 ATPase Assay of MERS-CoV nsp13
1. Dilute the purified MERS-CoV nspl3 to $0.5 \mu \mathrm{M}$ by SEC buffer.

2. Add the following reagents in turn to prepare the reaction mixture: $\mathrm{ddH}_{2} \mathrm{O}(36.5 \mu \mathrm{L}), 5 \times$ ATPase reaction buffer $(10 \mu \mathrm{L})$, ATP $(1 \mathrm{mM}, 2.0 \mu \mathrm{L})$, and $\left[\gamma^{-32} \mathrm{P}\right] \mathrm{ATP}(\sim \mathrm{nM}$, $1 \mu \mathrm{L})[18]$.

3. Add diluted nspl3 protein $(0.5 \mu \mathrm{M}, 2 \mu \mathrm{L})$ to the reaction mixture, incubate at $30{ }^{\circ} \mathrm{C}$ and start timing.

4. At each indicated time point, add $2 \mu \mathrm{L}$ quenching buffer (0.5 M EDTA) to the mixture to stop the reaction and place the mixture on ice. 


\subsection{Helicase Assay of MERS-CoV nsp13}

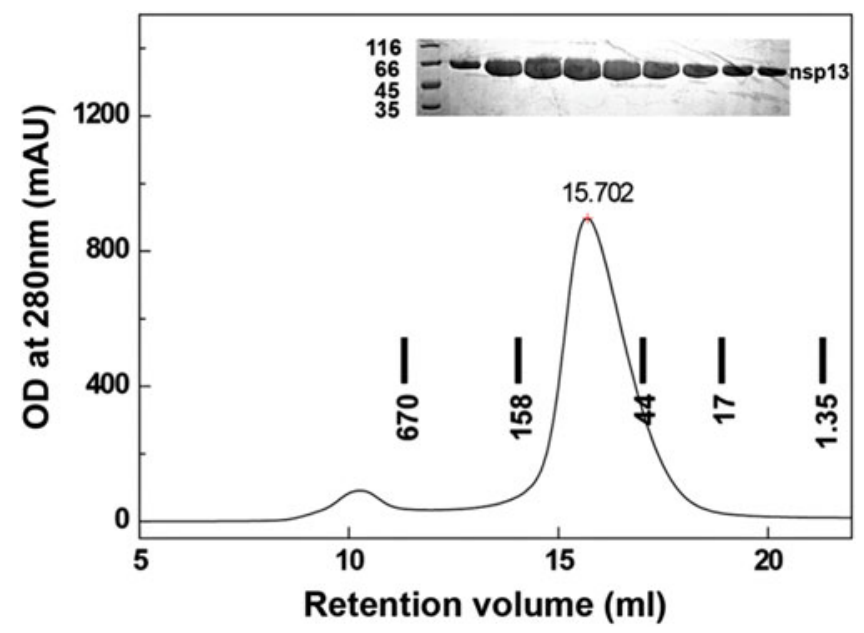

Fig. 2 Large-scale purification of MERS-CoV nsp13.MERS-CoV nsp13 eluted from Superdex $200300 / 10 \mathrm{GL}$ column precalibrated with gel filtration standards (thyroglobulin $670 \mathrm{kDa}, \gamma$-globulin $158 \mathrm{kDa}$, ovalbumin $44 \mathrm{kDa}$ and myoglobin $17 \mathrm{kDa}$ and vitamin $1.35 \mathrm{kDa}(1350 \mathrm{Da}))$. Upper insert, SDS-PAGE analysis of the purified protein

5. Spot $1 \mu \mathrm{L}$ sample from the mixture on the thin-layer chromatography cellulose TLC plates and resolve with running buffer for $20 \mathrm{~min}$.

6. Dry the plates and press the plate onto phosphor screen for $2 \mathrm{~h}$. Analyze the result by storage phosphor screen and Typhoon Trio Variable Mode Imager (Fig. 3).

1. Dilute the purified MERS-CoV nspl3 to $1 \mu \mathrm{M}$ by SEC buffer (see Note 4).

2. Add the following reagents in turn: $10 \times$ helicase reaction buffer $(1 \mu \mathrm{L}), \mathrm{H}_{2} \mathrm{O}(4 \mu \mathrm{L})$, Trap RNA $(3 \mu \mathrm{M}, 1 \mu \mathrm{L})$, partial duplex RNA substrate $(0.5 \mu \mathrm{M}, 1 \mu \mathrm{L})$, and diluted nspl3 protein $(0.5 \mu \mathrm{M}, 2 \mu \mathrm{L})$, ATP $(10 \mathrm{mM}, 1 \mu \mathrm{L})$. The final volume of each reaction mixture is $10 \mu \mathrm{L}$ [19].

3. Incubate the mixtures at $30{ }^{\circ} \mathrm{C}$ for $30 \mathrm{~min}$.

4. Add $2.5 \mu \mathrm{L} 5 \times$ loading buffer to the mixture to stop the reaction.

5. Take $4 \mu \mathrm{L}$ sample from each reaction mixtures and load the samples onto $10 \%$ native PAGE gel.

6. Run the native PAGE gel at $100 \mathrm{~V}$ for $40 \mathrm{~min}$ on ice.

7. Scan the gel (Fig. 4).

3.8 Crystallization of MERS-CoV nsp13
Crystals of the unliganded MERS-CoV nspl3 diffracted the X-rays poorly, >3.6 $\AA$. The addition of $5^{\prime}$-triphosphate-15 dT DNA (ppp-15T) greatly improves the resolution. 


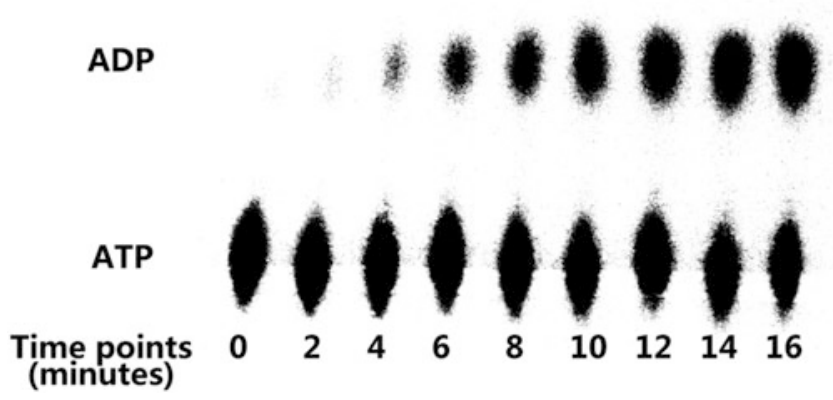

Fig. 3 ATPase activity of MERS-CoV nsp13. ATPase activity was measured by incubation at $30{ }^{\circ} \mathrm{C}$ for $0-16 \mathrm{~min}$

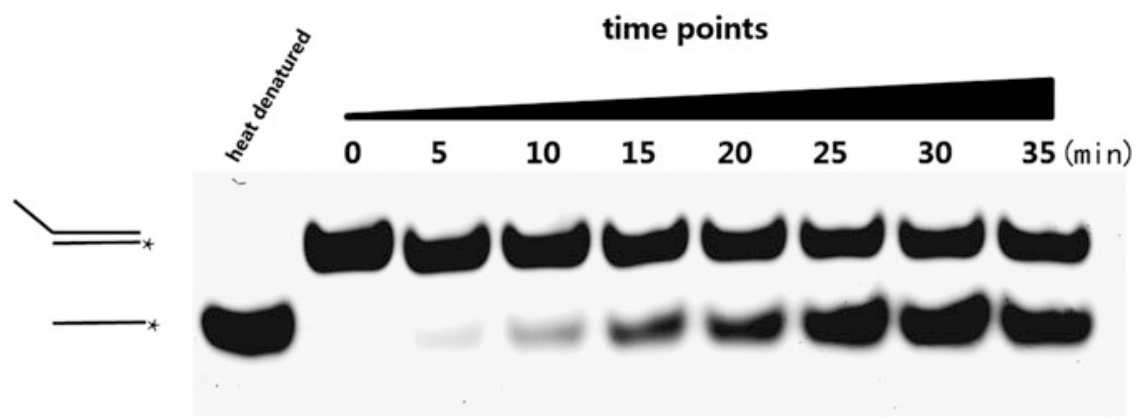

Fig. 4 Helicase activity of MERS-CoV nsp13. Activity was determined with the indicated RNA substrate (the asterisk marks the position of the HEX label). Samples were incubated at $30{ }^{\circ} \mathrm{C}$ for $0-35$ min

\subsection{Determination of MERS-CoV nsp13 Crystal Structure}

1. Mix the purified MERS-CoV nspl3 with $5^{\prime}$-triphosphate-15T DNA (ppp-15T) with 1:1.5 molar ratio and incubate at $4{ }^{\circ} \mathrm{C}$ overnight.

2. Mix $1 \mu \mathrm{L}$ sample with $1 \mu \mathrm{L}$ reservoir buffer from the crystallization conditions screen kits, and incubate at $18^{\circ} \mathrm{C}$ using the hanging-drop vapor-diffusion system.

3. Crystallize MERS-CoV nspl3 by mixing with the equal volume of reservoir buffer containing $0.1 \mathrm{M}$ Tris- $\mathrm{HCl}(\mathrm{pH} \mathrm{8.5})$, $1 \mathrm{M}(\mathrm{NH} 4)_{2} \mathrm{SO}_{4}$, and $15 \%$ glycerol. Crystals grow to their maximum in a week (Fig. 5 ).

1. Highly redundant multi-wavelength anomalous diffraction data should be collected using the X-ray with wavelengths close to the absorption edge of zinc. High energy remote wavelength should be $1.2810 \AA$, peak wavelength: $1.2827 \AA$ (two datasets were collected to improve the redundancy), and inflection wavelength $1.2831 \AA$.

2. Data processing and reducing by XDS Package and Truncate software from CCP4. The crystals belong to the space group $\mathrm{P}_{1} 22$, and contained two copies of nspl3 per asymmetric unit. 


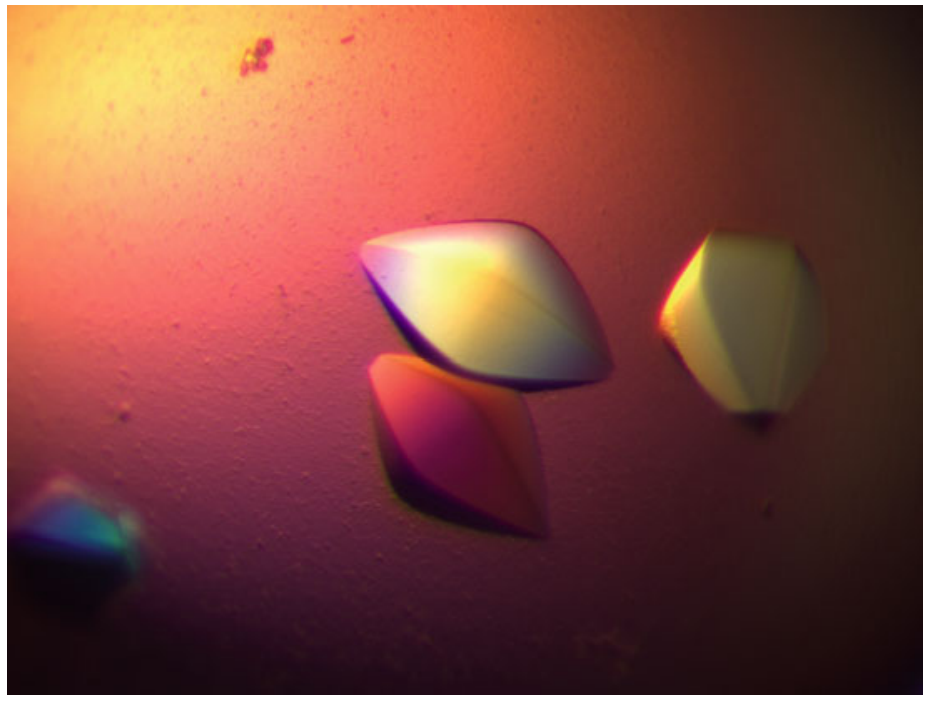

Fig. 5 Crystals of MERS-CoV nsp13. Nsp13 crystallized by incubation with $5^{\prime}$-triphosphate-15T DNA at $18^{\circ} \mathrm{C}$ using the hanging-drop vapor-diffusion system. The crystals are grown to the biggest in a week

3. An interpretable electron density map should be calculated using SHARP/autoSHARP [20].

4. Manually build the initial model of MERS-CoV nspl3 by Coot [21].

5. Collect native data with highest resolution $(3.0 \AA)$ using the X-rays with the wavelength of $0.978 \AA$.

6. Higher resolution structure should be solved by molecular replacement using the initial nspl3 structure as the searching model.

7. Manual model building with the improved electron density map. While most part of nspl3 can be located, the electron density of $1 \mathrm{~B}$ subdomain is very weak, reflecting that this part is highly flexible.

8. Structure refinement to resolution limit of $3.0 \AA$ A using software PHENIX [22].

In the final model (Fig. 6), 145-230aa (the entire 1B domain) of molecule $\mathrm{A}$ are disordered, probably due to mobility of $1 \mathrm{~B}$ and the lack of crystal contacts, whereas in molecule B, 591 out of 598 amino acids were located in the electron density maps (Fig. 7). Data collection and refinement statistics are summarized in Table 1. 


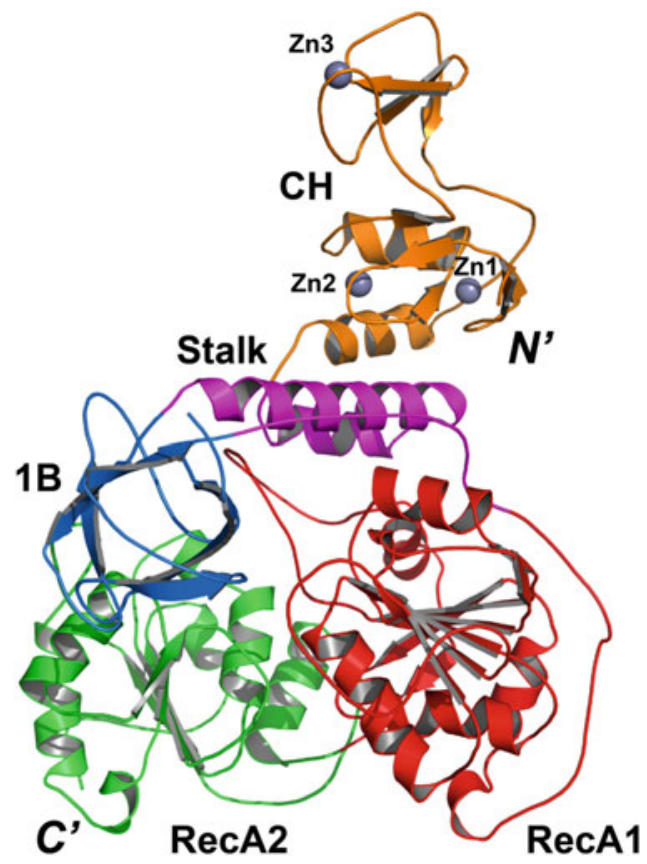

Fig. 6 Final model of MERS-CoV nsp13 structure. Model of MERS-CoV nsp13 containing $\mathrm{CH}$ (orange), Stalk (magenta), 1B (blue), RecA1 (red), and RecA2 (green) domains

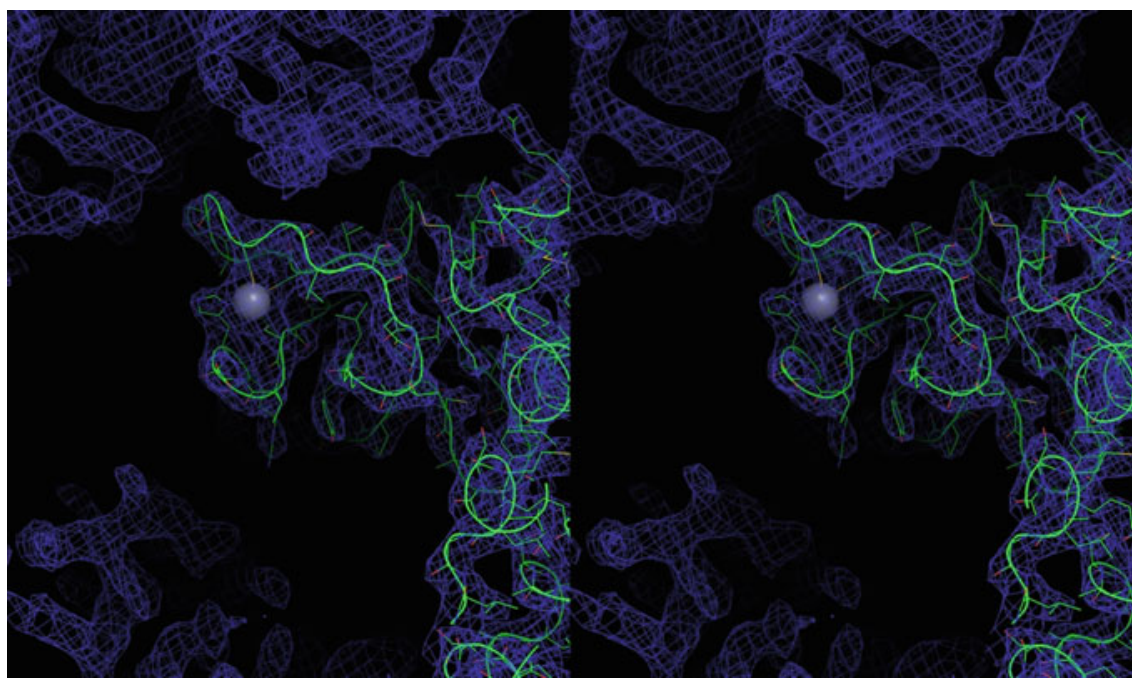

Fig. 7 Portion of the electron density map of MERS nsp13 crystal structure. A wall-eye stereo image of a portion of electron density map (zn3 binding site). 2Fo-Fc map is shown with blue mesh. The final model of MERS nsp13 (green) is superimposed. The zinc is shown with a gray sphere 


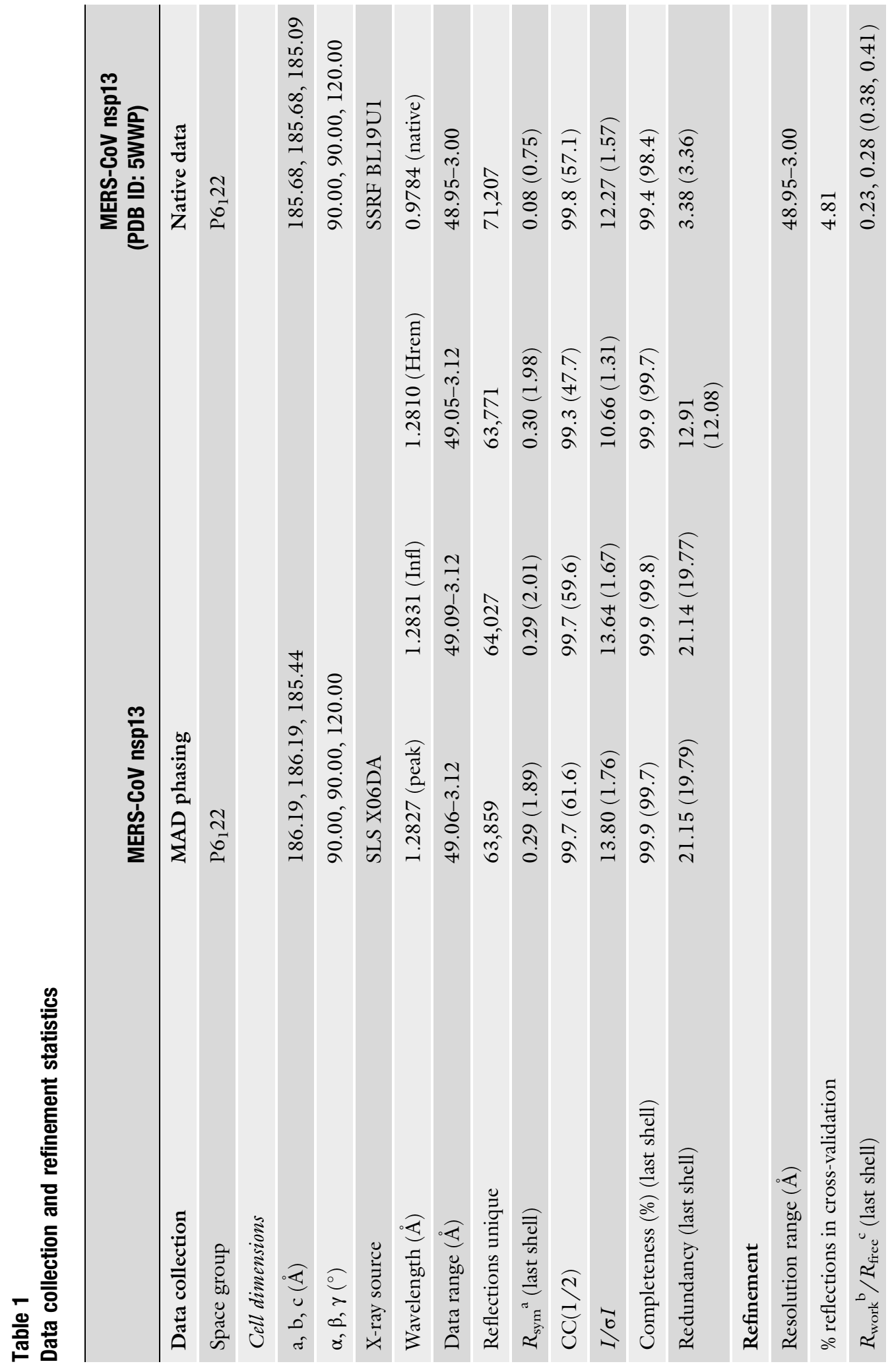




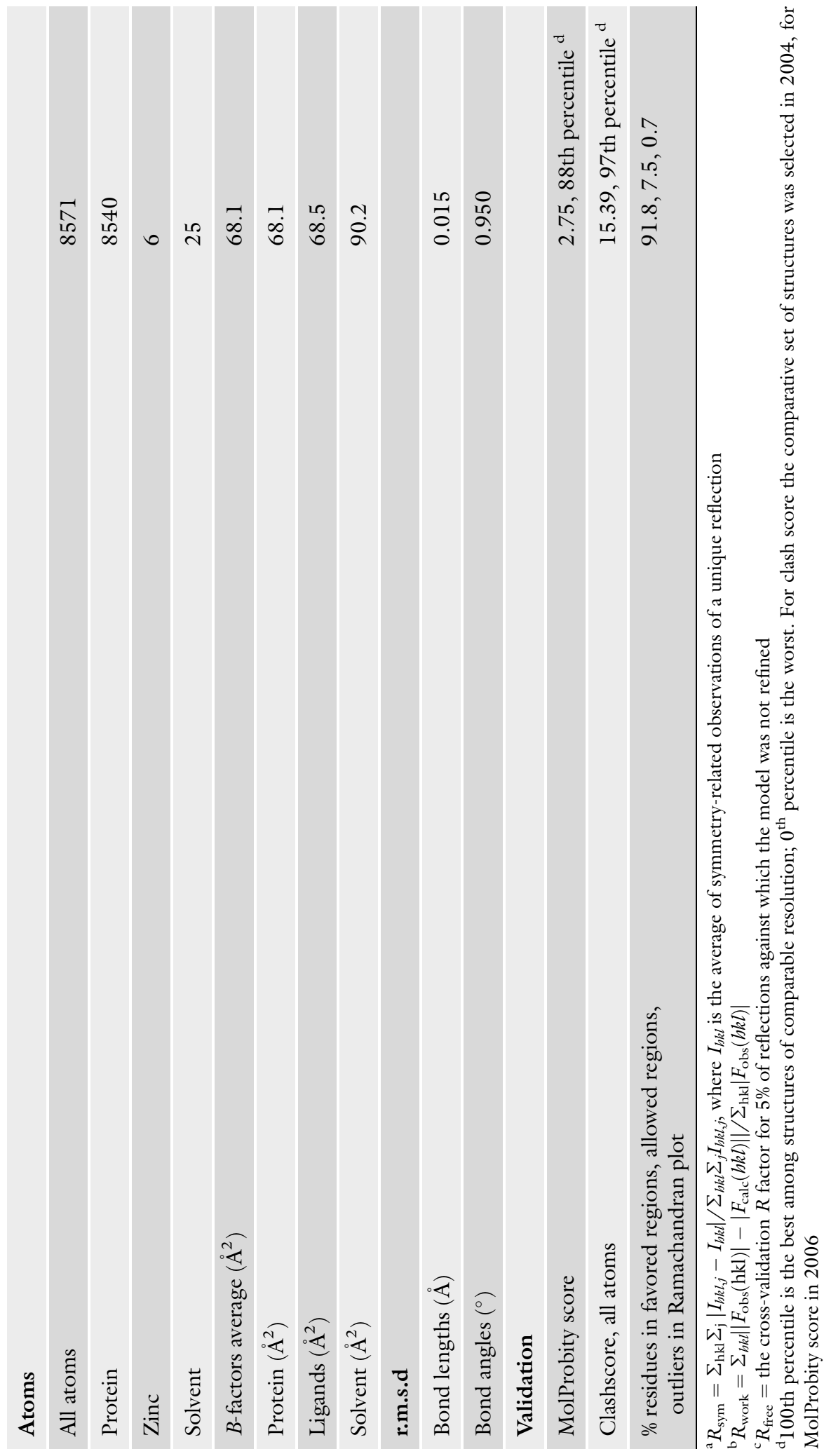




\section{Notes}

1. When we prepare Pl virus in six-well plates, the medium in the wells always evaporated. Sealing the gap of the plate by medical tape can reduce the evaporation of medium (don't seal the gap completely, leave a small gap to keep the ventilation). Having a water trough in incubator also can reduce the evaporation of the medium.

2. The culture of insect cells sometimes was harassed by the contamination of bacteria or other microbes. To avoid the contamination, we treat the conical flasks not only by conventional autoclave sterilization, but also leave the $3 \mathrm{~L}$ conical flask (sealed by tinfoil) in the oven at $200{ }^{\circ} \mathrm{C}$ for $3-5 \mathrm{~h}$ before using.

3. To remove nucleic acids bound to nspl3, we used the lysis buffer containing high concentrate salt; this is a key step and improves the crystallization of nspl3 [10]. In practice, when sonicated in the buffer containing high concentrate salt, we found that the SUMO-tagged recombinant proteins lead the supernatant of the high- $\mathbf{5}$ cell lysate to be turbid, which finally blocks the affinity columns. We have tried four concentrations of $\mathrm{NaCl}$ in lysis buffer, including $300 \mathrm{mM}, 500 \mathrm{mM}, 1 \mathrm{M}$, and 1.5 M. The first three concentrations of $\mathrm{NaCl}$ render the supernatant to be unable to use, we can't improve it by highspeed centrifugation $(47,850 \times g)$, and it also can't be filtered by $0.45 \mu \mathrm{m}$ syringe filter. The last concentration, $1.5 \mathrm{M} \mathrm{NaCl}$ in lysis buffer, could generate a bit better supernatant of cell lysates than other three concentrations of salt. We centrifuge the supernatant twice, then can filter it by $0.45 \mu \mathrm{m}$ syringe filters ( $100 \mathrm{~mL}$ supernatant consumed about $8-10$ filters). This clarified supernatant can flow through the affinity columns well.

4. The results of helicase assay always face the contamination of background fluorescence. Keep the gel from contacting any items containing fluorescence in the lab, including fluorescent dyes, some plastic boxes, hand towel, and so on.

\section{References}

1. Stadler K, Masignani V, Eickmann M, Becker S, Abrignani $S$ et al (2003) SARS--beginning to understand a new virus. Nat Rev Microbiol $1: 209-218$

2. Zaki AM, van Boheemen S, Bestebroer TM, Osterhaus AD, Fouchier RA (2012) Isolation of a novel coronavirus from a man with pneumonia in Saudi Arabia. N Engl J Med $367: 1814-1820$
3. Kupferschmidt K (2015) INFECTIOUS DISEASES. Amid panic, a chance to learn about MERS. Science 348:1183-1184

4. Gorbalenya AE, Enjuanes L, Ziebuhr J, Snijder EJ (2006) Nidovirales: evolving the largest RNA virus genome. Virus Res 117:17-37

5. Lauber C, Goeman JJ, Parquet Mdel C, Nga PT, Snijder EJ et al (2013) The footprint of genome architecture in the largest genome 
expansion in RNA viruses. PLoS Pathog 9: el003500

6. Thiel V, Ivanov KA, Putics A, Hertzig T, Schelle B et al (2003) Mechanisms and enzymes involved in SARS coronavirus genome expression. J Gen Virol 84:2305-2315

7. Subissi L, Imbert I, Ferron F, Collet A, Coutard B et al (2014) SARS-CoV ORFlbencoded nonstructural proteins 12-16: replicative enzymes as antiviral targets. Antivir Res 101:122-130

8. Subissi L, Posthuma CC, Collet A, Zevenhoven-Dobbe JC, Gorbalenya AE et al (2014) One severe acute respiratory syndrome coronavirus protein complex integrates processive RNA polymerase and exonuclease activities. Proc Natl Acad Sci U S A 111: E3900-E3909

9. Prentice E, McAuliffe J, Lu X, Subbarao K, Denison MR (2004) Identification and characterization of severe acute respiratory syndrome coronavirus replicase proteins. J Virol 78:9977-9986

10. Hao W, Wojdyla JA, Zhao R, Han R, Das R et al (2017) Crystal structure of Middle East respiratory syndrome coronavirus helicase. PLoS Pathog 13:el006474

11. Gorbalenya AE, Koonin EV (1989) Viral proteins containing the purine NTP-binding sequence pattern. Nucleic Acids Res 17:8413-8440

12. Deng Z, Lehmann KC, Li X, Feng C, Wang G et al (2014) Structural basis for the regulatory function of a complex zinc-binding domain in a replicative arterivirus helicase resembling a nonsense-mediated mRNA decay helicase. Nucleic Acids Res 42:3464-3477

13. Ivanov KA, Thiel V, Dobbe JC, van der Meer Y, Snijder EJ et al (2004) Multiple enzymatic activities associated with severe acute respiratory syndrome coronavirus helicase. J Virol 78:5619-5632
14. Adedeji AO, Lazarus H (2016) Biochemical characterization of Middle East respiratory syndrome coronavirus helicase. mSphere 1. https://doi.org/10.1128/mSphere. 00235-16

15. Hu Z, Yan C, Liu P, Huang Z, Ma R et al (2013) Crystal structure of NLRC4 reveals its autoinhibition mechanism. Science 341:172-175

16. Zlatev I, Lackey JG, Zhang L, Dell A, McRae K et al (2013) Automated parallel synthesis of $5^{\prime}$-triphosphate oligonucleotides and preparation of chemically modified $5^{\prime}$-triphosphate small interfering RNA. Bioorg Med Chem 21:722-732

17. Zlatev I, Manoharan M, Vasseur JJ, Morvan F (2012) Solid-phase chemical synthesis of 5'-triphosphate DNA, RNA, and chemically modified oligonucleotides. Curr Protoc Nucleic Acid Chem. Chapter 1: Unitl 28

18. Cui S, Eisenacher K, Kirchhofer A, Brzozka K, Lammens A et al (2008) The C-terminal regulatory domain is the RNA $5^{\prime}$-triphosphate sensor of RIG-I. Mol Cell 29:169-179

19. Lee NR, Kwon HM, Park K, Oh S, Jeong YJ et al (2010) Cooperative translocation enhances the unwinding of duplex DNA by SARS coronavirus helicase nsP13. Nucleic Acids Res 38:7626-7636

20. Vonrhein C, Blanc E, Roversi P, Bricogne G (2007) Automated structure solution with autoSHARP. Methods Mol Biol 364:215-230

21. Emsley P, Lohkamp B, Scott WG, Cowtan K (2010) Features and development of coot. Acta Crystallogr D Biol Crystallogr 66:486-501

22. Adams PD, Afonine PV, Bunkoczi G, Chen VB, Davis IW et al (2010) PHENIX: a comprehensive python-based system for macromolecular structure solution. Acta Crystallogr D Biol Crystallogr 66:213-221 